\title{
Resenha
}

\section{Escola: os piores anos de minha vida, de James Patterson e Chris Tebbetts}

http://dx.doi.org/10.5007/2178-4582.2016v50n1p262

Adilson Januario da Silva

Universidade Nove de Julho, Bauru/SP, Brasil

\section{Resenha de ${ }^{1}$ :}

PATTERSON, J. ; TEBBETTS, C. Escola: os piores anos de minha vida. Tradução de Ana Ban. São Paulo: Arqueiro, 2013, 288 p.

A relação entre aluno e escola tem sido tema de inúmeros trabalhos acadêmicos, sob os mais variados enfoques, sejam psicológicos, sociológicos, antropológicos, filosóficos e psicanalíticos, sendo este um assunto bastante relevante para quem sobre ele se debruça na tarefa de entender o espaço escolar e a forma como este é representado no imaginário de seu sujeito principal: o aluno.

Em Escola, os piores anos de minha vida, Patterson e Tebbetts, trazem subsídios a estas discussões, através de Rafa Khatchadorian, personagem principal, que logo no primeiro capítulo se auto intitula "herói trágico". Rafa é um aluno do sexto ano da Escola Municipal de Hills Village, filho de Jules, uma mulher que trabalha dois turnos em uma lanchonete para sustentar a família que, além de Rafa, ainda é composta por Georgia, irmã que ele apresenta como "insuportável", e Carl, seu padrasto, denominado por ele "Urso". Ele ainda tem um grande amigo, inseparável, chamado Leonardo Caladão.

O livro desde o início é bastante interessante e estimula sua leitura pela maneira como o texto é construído, na primeira pessoa, em forma de diálogo entre a personagem principal, Rafa, e o leitor, como se o mesmo estivesse a contar sua história, buscando uma cumplicidade entre ambos. Ele mesmo intitula o livro de "autobiografia" e no primeiro capítulo vai logo dizendo: “[...] me entender (quer dizer, entender de verdade a mim e à minha vida maluca) não é assim muito fácil. Por isso acho tão difícil encontrar pessoas confiáveis" (p. 6). Rafa deixa claro que só confia em sua mãe, Jules, e em seu amigo Leonardo e busca confiar no leitor, ao dizer: "vamos ver se eu posso confiar em você" (p. 6). As ilustrações acompanham os textos o tempo todo, sendo que

Do original: Middle School, the worst years of my life. Nova York: Little, Brown and Company, 2011. 
em alguns capítulos, elas são o próprio texto. Rafa atribui as ilustrações ao seu amigo e mentor Leonardo Caladão, que é de poucas palavras e não fala com mais ninguém, a não ser com ele. Isso acontece porque no decorrer da história, Rafa revela a verdade sobre esse seu amigo inseparável: Leonardo era seu irmão gêmeo, que aos três anos de idade teve uma meningite e faleceu. Desde então, ele se tornou um amigo imaginário de Rafa, com o qual dialogava constantemente, pedia conselhos, arquitetava suas artimanhas e principalmente chorava suas mágoas. Rafa apresenta Leo como "Louco e Irado com L e I maiúsculos, mas (que) está sempre com os pés no chão" (p. 8).

Em casa, Rafa vivia uma situação um tanto quanto complicada com o padrasto, Carl, o Urso, pois passava os dias sem trabalhar, deitado no sofá, tomando energéticos, além de implicar o tempo todo com ele e com sua irmã; seu quarto é o "único lugar", onde ele pode "relaxar, ficar sozinho e fazer tudo o que quiser" (p. 46), ou seja, ali cria e recria seu mundo, dá asas a sua imaginação e reflete sobre tudo que o cerca, inclusive sobre as pessoas com as quais se relaciona. Mas é a escola o grande foco de sua autobiografia.

De início, ele chama atenção do leitor para uma ilustração (p. 7): "Esse aí sou eu, chegando à 'prisão' - também conhecida como Escola Municipal de Hills Village - no carro de Jules" (p. 6). Ele ainda diz que na época em "que construíram esta escola, ela era "uma prisão para adultos" e que "agora é uma prisão para alunos de sexto, sétimo, oitavo e nono ano" (p. 11). A seguir, começa a apresentar as outras personagens da escola como a professora de inglês Donatella Carrasco, a "Mulher Dragão", também responsável pelo "castigo depois da aula" (p. 8); Ida Severo é a coordenadora, que fica no que ele chama de "calabouço" (p. 115); o diretor David é o "Rei Lagarto", que fica numa "câmara interna fria e úmida" (p. 117).

A “Operação R.A.F.A” (Regras Atrapalham a Felicidade Alheia) é o que dá movimento a toda história, pois através dela, Rafa tenta burlar as regras estabelecidas para os alunos, sendo que cada quebra de normas equivale à uma pontuação, criada por ele e Leonardo Caladão. A operação só não aceitava que suas ações prejudicassem outras pessoas; os prejuízos deveriam ser somente de Rafa. Desta forma ele queria ser lembrado para o resto da história daquela escola. Ao mesmo tempo em que colocava a Operação RAFA em funcionamento, ele tinha que se safar das perseguições de Miller Matador, o valentão da escola, que não aceitava que Rafa se tornasse mais popular que ele. Toda atmosfera de baixo astral, de sofrimento dentro da escola só é quebrada quando Rafa se refere a Jeanne Galletta, que segundo ele é "simplesmente linda", e que "dava vontade de ficar olhando o rosto dela para sempre" (p. 24).

Neste universo, Rafa vive seu cotidiano e tenta, de alguma forma, transforma-lo à maneira que ele concebe como melhor, mais divertido, mais ver- 
dadeiro e justo. Rafa é o retrato de muitos de nossos alunos, com seus medos, inseguranças, fantasias, impulsividades, genialidades, enfim, arcabouço de sentimentos que demonstram, nada mais nada menos, que a busca por uma autoafirmação, num processo de construção de suas identidades. Nesse processo, os conflitos internos são por vezes inevitáveis e isso pode ser exteriorizado facilmente, fazendo com que a agressividade tome proporções descontroladas.

“As pessoas sempre falam sobre como crescer é maravilhoso. Mas eu só via cada vez mais regras e mais adultos me dizendo o que eu podia e não podia fazer, em nome do que é "para o meu próprio bem"” (p. 30). A personagem demonstra nesta reflexão (e durante todo o capítulo 5) que as regras não the fazem sentido, e desta forma, a escola é um lugar sem sentido, porque ele a concebe a partir das regras que estabelece, com uma porção de "proibidos" e "nãos". A escola é uma prisão e justifica o subtítulo do livro: "os piores anos de minha vida". Lidamos (ou pelo menos tentamos lidar) com esse tipo de comportamento em nosso cotidiano escolar diariamente e às vezes achamos que a falta de interesse, o desânimo, a agressividade excessiva, a falta de comprometimento de nossos alunos é inerente à sua idade (adolescência, juventude) e que o tempo e a idade irá mostrar a importância da escola pra sua vida. O que não paramos muitas vezes para refletir, é que a cultura escolar muitas vezes concebida de forma engessada, peca ao querer moldar o aluno numa fôrma já pré-estabelecida, sem que se atente para suas potencialidades. Ressaltamos as deficiências e as características que julgamos inadequadas e não damos a devida atenção às qualidades, que muitas vezes são seus verdadeiros talentos. É dessa forma que a professora e a direção da escola encontram um caminho (porque muitas vezes não há uma solução absoluta) para lidar com o comportamento de Rafa, que para além da punição, buscam desenvolver suas potencialidades e melhorar de alguma forma sua relação com a escola.

Submissão em: 22/04/2015

Revisão em: 27/04/2015

Aceite em: 17/03/2016

Adilson Januario da Silva é doutorando no Programa de Pós-graduação em Educação da UNINOVE, São Paulo/SP. Endereço para correspondência: Avenida Francisco Matarazzo n ${ }^{\circ} 612-1 .^{\circ}$ andar Prédio A, Bairro Água Branca, São Paulo/SP, Brasil

CEP: 05001-100

E-mail: adjanu@yahoo.com.br 